\title{
Hak Pasien Untuk Didampingi Keluarga Dalam Pelayanan Kesehatan (Kajian Yuridis Undang-Undang Nomor 44 Tahun 2009 Tentang Rumah Sakit)
}

\author{
Supeno $^{1)}$, Warfian Saputra ${ }^{2)}$ \\ Fakultas Hukum Universitas Batanghari ${ }^{1,2)}$ \\ Jalan Slamet Riyadi Broni Kota Jambi (0741) 65351 \\ Email :msasyabani@gmail.com
}

\begin{abstract}
Increasing public awareness of the importance of health then protection against patients in Hospitals is a very important issue for review because it has been going on a wide variety of acts committed by the parties of certain detriment of patients such as the occurrence of sexual harassment in the service of health, this happens because the patient did not receive the full accompaniment of families in Ministry of health, legally this right is not set explicitly in the Act No. 44 of the year 2009 Of the hospital so that the patient's legally difficult to prove was the occurrence of sexual harassment against him, therefore this Act must give full rights to the patient for his family accompanied in each health service acquired in the hospital, a change in the law this is a thing that needs to be done immediately so that the patient gets legal protection so that similar cases could be minimised so that public confidence against the hospital will progressively increase.
\end{abstract}

Keyword: patient rights, protection

\section{PENDAHULUAN}

Kesehatan merupakan kebutuhan yang sangat mendasar bagi setiap orang, masalah kesehatan merupakan unsur penting dalam kehidupan manusia maka setiap orang berhak untuk hidup sehat dan memperoleh pelayanan kesehatan serta setiap orang mempunyai kesempatan yang sama dalam memperoleh pelayanan kesehatan. Kesempatan memperoleh pelayanan kesehatan dijamin oleh konstitusi Indonesia yang termuat dalam Pasal $28 \mathrm{H}$ ayat (1) UUD 1945 hasil amandemen kedua yang mengatur bahwa setiap orang berhak hidup sejahtera lahir dan batin, bertempat tinggal, dan mendapatkan lingkungan hidup yang baik dan sehat serta berhak memperoleh pelayanan kesehatan.

Kesehatan menyangkut semua segi kehidupan manusia dan ruang lingkupnya sangat luas, dalam sejarah perkembangannya telah terjadi perubahan orientasi pemikiran mengenai upaya pemecahan masalah kesehatan, proses perubahan tersebut sejalan dengan perkembangan ilmu pengetahuan, teknologi dan sosial budaya masyarakat sehingga upaya kesehatan tidak hanya sekedar penyembuhan saja akan tetapi menyangkut upaya-upaya yang luas, menurut Departemen Kesehatan Republik Indonesia bahwa upaya-upaya kesehatan tersebut menyangkut "upaya peningkatan (promotif), pencegahan (preventif), penyembuhan (kuratif) dan pemulihan (rehabilitatif) yang bersifat menyeluruh, terpadu dan berkesinambungan". ${ }^{1}$

Sarana kesehatan yang diselenggarakan oleh pemerintah berupa rumah sakit pemerintah, puskesmas, puskesmas pembantu, polindes, bidan desa, sumber pembiayaannya berasal dari pemerintah, sedangkan sumber daya kesehatan yang diselenggarakan oleh masyarakat adalah rumah sakit swasta, dokter praktik swasta baik perorangan maupun praktik bersama, Bidan Praktik Swasta (BPS) dan sebagainya, terjaminnya upaya kesehatan yang baik sangat tergantung kepada upaya pembinaan sumber daya kesehatan yang baik pula. "Pelayanan kesehatan (health care services) merupakan salah satu upaya yang dapat dilakukan untuk meningkatkan derajat kesehatan baik perseorangan, maupun kelompok atau masyarakat secara keseluruhan". ${ }^{2}$

Menurut Bambang Giatno, Kepala Badan PPSDM Kesehatan Republik Indonesia menyatakan bahwa arah pembinaan sumber daya manusia (SDM) kesehatan adalah "tenaga kesehatan yang berkualitas, tenaga kesehatan yang beretika dan berdedikasi, merata dalam

\footnotetext{
${ }^{1}$ Depkes RI, Sistem Kesehatan Nasional, Jakarta, 1987, hal.3.

${ }^{2}$ Lihat Veronica Komalawati, “Aspek Hukum Dalam Pelayanan Kesehatan : Suatu Kajian”, Jurnal Hukum Bisnis, hal.17.
} 
jumlah dan jenis yang memadai". ${ }^{3}$ Permasalahan tenaga kesehatan yang kurang berkualitas dan kurang beretika menjadi isu yang mengemuka akhir-akhir ini, banyak kasus terjadinya kesalahan tindakan medik dikarenakan tidak mampunya tenaga kesehatan melakukan pertolongan sesuai dengan standar yang ditetapkan, dalam kasus lain juga ditemukan kurangnya etika tenaga kesehatan dalam memberikan pelayanan kepada masyarakat seperti kurang ramah terutama terhadap pasien miskin, suka marah dan berbicara kurang sopan. Oleh karena itu arah pembinaan sumber daya manusia (SDM) kesehatan tersebut harus menjadi agenda utama pembinaan sumber daya kesehatan agar tenaga kesehatan memiliki kualitas keilmuan dan ketrampilan, beretika dan berdedikasi.

Menurut Endang Kusuma Astuti bahwa "tenaga kesehatan yang berkualitas diukur dari standar profesi yang telah dirumuskan oleh organisasi profesi (IDI) yaitu standar ketrampilan, standar sarana, standar perilaku dan standar catatan medis". ${ }^{4}$

Dalam upaya untuk memenuhi kebutuhan akan tenaga kesehatan yang merata dalam jumlah dan jenis yang memadai dapat ditempuh dengan cara menyelenggarakan pendidikan tenaga kesehatan baik yang diselenggarakan oleh pemerintah maupun masyarakat, dengan mencetak tenaga kesehatan maka diharapkan penyebaran tenaga kesehatan akan merata. Dalam hal ini masyarakat merasakan kurangnya tenaga kesehatan yang sesuai dengan kebutuhan karena banyak tenaga kesehatan yang enggan bertugas di daerah-daerah yang terpencil yang sebenarnya sangat membutuhkan tenaga kesehatan terutama dokter, permasalahan lain adalah fasilitas kesehatan dan biaya alat kesehatan yang relatif mahal. Pemerintah berusaha menyediakan dana dan melakukan kontrol terhadap barang dan jasa pelayanan kesehatan dengan cara memaksimalkan akses barang dan/atau jasa termasuk biaya kesehatan, menurut Elfindri kontrol pemerintah terhadap barang dan jasa pelayanan kesehatan dilakukan atas dasar pertimbangan penting yakni

\section{${ }^{3}$ Bambang Giatno, "Kebijakan DEPKES}

Dalam Pengadaan Sumber Daya Manusia (SDM) Bidan", Kongres XIV IBI, Padang, 3 Nopember 2008.

${ }^{4}$ Endang Kusuma Astuti, Transaksi Terapeutik dalam Upaya Pelayanan Medis di Rumah Sakit, PT. Citra Aditya Bhakti, Semarang, 2009, hal.33. "menghindarkan salah alokasi dalam pembiayaan, menjaga agar tidak terjadi ketimpangan pembiayaan, menghindari agar tidak terjadi pemborosan, dan menghindari pembengkakan pembiayaan". ${ }^{5}$ Akan tetapi upaya ini belum secara maksimal dapat dilaksanakan oleh pemerintah yang mengakibatkan banyak rumah sakit pemerintah tidak memiliki peralatan yang memadai sesuai dengan tuntutan akan kebutuhan pelayanan kesehatan masyarakat dewasa ini.

Layanan kesehatan dewasa ini berkembang begitu pesat, hal tersebut menunjukkan adanya iklim yang baik dalam bisnis layanan kesehatan ditunjang dengan semakin baiknya tingkat kesadaran masyarakat akan pentingnya kesehatan, dengan demikian diharapkan akses masyarakat terhadap pusat layanan kesehatan menjadi lebih besar. Walaupun demikian bukan berarti kesempatan tersebut dengan mudah diperoleh akan tetapi harus memenuhi persyaratan-persyaratan yang telah ditentukan oleh pemerintah berdasarkan perundang-undangan yang berlaku, dan karena biasanya yang membuka bisnis layanan kesehatan ini adalah dokter maka perlu juga adanya pengawasan dari organisasi profesi karena praktik yang dilakukan dalam layanan kesehatan sangat erat hubungannnya dengan profesi kedokteran.

Permasalahan etika profesi sangat penting untuk menjadi perhatian dan pegangan bagi para tenaga kesehatan karena dengan berpedoman kepada etika profesi dapat terhindar dari kemungkinan terjadinya kesalahan dan kelalaian dalam menjalankan tugas keprofesiannya. Produk perundang-undangan dan kebijakan pemerintah yang mengatur tentang kesehatan ataupun yang berhubungan dengan kesehatan cukup banyak dari tingkat undang-undang, peraturan pemerintah, peraturan menteri kesehatan dan keputusan menteri kesehatan hal ini menunjukkan bahwa permasalahan kesehatan merupakan salah satu hal penting yang harus mendapatkan perhatian khusus dari pemerintah karena permasalahan kesehatan sangat kompleks dan dinamis dan menyangkut hajat hidup orang banyak.

Hal di atas merupakan contoh kasus yang perlu disoroti dengan serius, dalam konteks ini adalah tentang kewajiban dan hak antara pasien dengan Rumah Sakit sebagai sarana pelayanan

${ }^{5}$ Elfindri, Ekonomi Layanan Kesehatan, Andalas Press, Padang, 2003, hal.27. 
kesehatan, kewajiban dan hak tersebut menjadi isu sentral dalam beberapa waktu belakangan ini, pasien sebagai pemakai jasa menjadi pihak yang sering dirugikan jika terjadi permasalahan dalam hubungan antara pasien dan dokter, demikian pula sebaliknya rumah sakit menjadi pihak yang sering dipersalahkan dalam pemberian pelayanan kesehatan. Intensitas gugatan terhadap pelayanan tenaga kesehatan terutama dokter dan rumah sakit semakin meningkat, M.C. Inge Hartini menyatakan sebagaimana yang dikutip oleh Muladi bahwa: Dalam majalah Tempo edisi Maret 2004 serangkaian gugatan pasien terhadap dokter maupun rumah sakit muncul ke permukaan. Tampaknya fenomena ini akan semakin meningkat seiring dengan peningkatan pendidikan dan kesadaran masyarakat akan hakhaknya. ${ }^{6}$

Permasalahan pemenuhan hak pasien menjadi suatu permasalahan yang perlu mendapatkan perhatian yang lebih besar dari semua kalangan karena permasalahan ini menyangkut kepentingan orang banyak, semakin tinggi tingkat pendidikan dan kesadaran masyarakat semakin tinggi pula intensitas gugatan oleh pasien terhadap rumah sakit. Bahder Johan Nasution menyatakan bahwa:

Munculnya kasus-kasus di bidang kesehatan merupakan indikasi bahwa kesadaran hukum masyarakat semakin meningkat. Semakin sadar masyarakat akan aturan hukum semakin mengetahui mereka akan hak dan kewajibannya dan semakin luas pula suarasuara yang menuntut agar hukum memainkan peranannya di bidang kesehatan. ${ }^{7}$

Salah satu hak pasien yang masih luput dari perhatian pembuat undang-undang adalah hak pasien untuk didampingi oleh keluarga dalam ruang dan kondisi tertentu, sebagai akibat ketiadaan hak tersebut dalam dalam peraturan perundang-undangan maka terjadi kasus pelecehan seksual dalam layanan kesehatan, sehingga peneliti menilai adanya kekosongan hukum.

Dengan kondisi demikian maka peneliti akan melakukan analisis dan kritik, dengan analisis dan kritik tersebut diharapkan akan dilakukan penyempurnaan terhadap undang-

${ }^{6}$ Muladi, Hak Asasi Manusia, Refika Aditama, Bandung, 2009, hal.186.

${ }^{7}$ Bahder Johan Nasution, Hukum Kesehatan Pertanggungjawaban Dokter,Rineka CiptaJakarta, 2005, hal.4. undang ini terutama ketentuan yang mengatur tentang kewajiban dan hak antara pasien dengan rumah sakit, dengan dilakukannya penyempurnaan terhadap pengaturan tentang kewajiban dan hak antara pasien dengan rumah sakit diharapkan dapat memberikan kepastian hukum bagi pasien dan rumah sakit. Menurut Bahder Johan Nasution "Dalam rangka pembangunan sektor kesehatan yang demikian kompleks dan luas, sangat dirasakan, bahwa peraturan perundang-undangan yang mendukung upaya kesehatan perlu lebih disempurnakan dan ditingkatkan". 8 Penyempurnaan tersebut penting untuk dilaksanakan karena permasalahan kesehatan sangat kompleks dan sangat luas apalagi dalam era globalisasi dewasa ini, "posisi bidang kesehatan menurut WTO/GATS menyatakan antara lain bahwa profesi dokter dan dokter gigi saat ini termasuk dalam sektor jasa bisnis". 9 Dari pemaparan dalam pendahuluan tersebut maka dapat dirumuskan beberapa permasalahan yang akan diteliti yaitu bagaimana pengaturan hak pasien untuk didampingi keluarga terdekat dalam kondisi dan ruang tertentu dalam perspektif Undang-Undang Nomor 44 tahun 2009 Tentang Rumah Sakit? dan bagaimana urgensi hak pasien untuk didampingi keluarga dalam kondisi dan ruang tertentu dalam pelayanan kesehatan?

\section{METODE PENELITIAN Tipe Penelitian}

Sebagai konsekuensi pemilihan topik yang akan dikaji dalam penelitian yang objeknya adalah permasalahan hukum tentang kewajiban dan hak pasien dan rumah sakit, maka tipe penelitian yang digunakan adalah penelitian juridis normatif, yakni penelitian yang difokuskan untuk mengkaji kaedah-kaedah atau norma-norma dalam hukum positif.

\section{Pendekatan yang digunakan}

Dikarenakan penelitian ini adalah penelitian hukum normatif, maka pendekatan yang akan digunakan adalah pendekatan konseptual (conceptual approach) yaitu dengan cara meneliti teori-teori dan asas-asas hukum yang berkaitan dengan hak-hak pasien di dalam peraturan perundang-undangan di Indonesia, pendekatan perundang-undangan (normative

\footnotetext{
${ }^{8}$ Bahder Johan Nasution, Ibid, hal.3.

${ }^{9}$ www. STADTAUS.com, Perlindungan
} Konsumen Kesehatan Berkaitan Dengan Malpraktik Medik, diakses tanggal 7 Juni 2010. 
approach) dengan cara meneliti ketentuanketentuan yang mengatur tentang hak-hak pasien baik yang tertuang dalam sistem peraturan perundang-undangan di Indonesia, dan pendekatan psicho-legal masyarakat Indonesia dalam menuntut haknya dalam pelayanan kesehatan.

\section{Pengumpulan Bahan Hukum}

Bahan-bahan hukum yang telah diperoleh akan diinventarisir dan diidentifikasi untuk digunakan sebagai bahan menganalisis pokok permasalahan dalam penelitian ini. Identifikasi bahan hukum primer, sekunder maupun tertier dilakukan secara kritis, logis dan sistematis, dikumpulkan berdasarkan sistem kartu (card system), hal ini dilakukan untuk mempermudah proses pengolahan bahan hukum tersebut, dengan demikian bahan hukum akan disusun dan dikelompokkan menurut bentuk, jenis dan tingkatannya. Adapun bahan hukum yang digunakan dalam penelitian ini adalah sebagai berikut:

a. Bahan hukum primer, yaitu bahan hukum yang berasal dari Undang-Undang Nomor 44 tahun 2009 Tentang Rumah Sakit, UndangUndang Nomor 36 Tahun 2009 Tentang Kesehatan, Undang-Undang Nomor 36 Tahun 2014 Tentang Tenaga Kesehatan yang digunakan untuk mempertajam analisis yang dilakukan yang ada hubungan dengan permasalahan yang dibahas.

b. Bahan hukum sekunder, adalah bahan hukum yang diperoleh dari bahan-bahan pendukung yang menjelaskan bahan hukum primer yaitu dengan mempelajari buku-buku dan literatur ilmiah lainnya yang ada relevansinya dengan penelitian ini.

c. Bahan hukum tertier adalah bahan yang dapat memberikan petunjuk maupun penjelasan terhadap bahan hukum primer dan sekunder seperti Black Law Dictionary, Kamus Hukum, Kamus Besar Bahasa Indonesia, dan sebagainya.

\section{Analisis bahan hukum}

Yaitu semua bahan hukum yang telah dikumpulkan baik itu bahan hukum primer maupun bahan hukum sekunder yang berhubungan dengan kewajiban dan hak antara pasien dengan rumah sakit serta bahan hukum tertier diseleksi dan dinilai dari aspek hukum, apakah bahan hukum tersebut ada hubungan dan memperkuat serta mendukung jawaban atas permasalahan yang berhubungan dengan pengaturan kewajiban dan hak antara pasien dengan Rumah Sakit. Bahan hukum yang telah diseleksi dan ada hubungan dengan permasalahan tersebut diklasifikasi sesuai dengan tingkat relevansinya. Bahan hukum kemudian dianalisis dan dikaji dan menarik kesimpulan dari semua permasalahan yang dibahasi, kajian dilakukan sedemikian rupa sehingga menggambarkan permasalahan dan pemecahannya secara jelas dan komprehensif.

\section{HASIL DAN PEMBAHASAN}

Hak pasien untuk didampingi keluarga dalam pelayanan kesehatan menurut UndangUndang Nomor 44 tahun 2009 Tentang Rumah Sakit

Jika dibaca hak-hak pasien yang diatur dalam Pasal $32^{10}$ Undang-Undang Nomor 44

\footnotetext{
${ }^{10}$ Setiap pasien mempunyai hak:

a. Memperoleh informasi mengenai tata tertib dan peraturan yang berlaku di Rumah Sakit

b. Memperoleh informasi tentang hak dan kewajiban pasien

c. Memperoleh layanan yang manusiawi, adil, jujur, dan tanpa diskriminasi

d. Memperoleh layanan kesehatan yang bermutu sesuai dengan standar profesi dan standar prosedur operasional

e. Memperoleh layanan yang efektif dan efisien sehingga pasien terhindar dari kerugian fisik dan materi

f. Mengajukan pengaduan atas kualitas pelayanan yang didapatkankan

g. Memilih dokter atau kelas perawatan sesuai dengan keinginannya dan peraturan yang berlaku di Rumah Sakit

h. Meminta konsultasi tentang penyakit yang dideritanya kepada dokter lain yang mempunyai Surat Izin Praktik baik di dalam maupun di luar Rumah Sakit

i. Mendapatkan privasi dan kerahasiaan penyakit yang dideritanya termasuk data-data medisnya

j. Mendapatkan informasi yang meliputi diagnosis dan tata cara tindakan medis, tujuan tindakan medis, alternatif tindakan, resiko dan komplikasi yang mungkin terjadi, dan prognosis terhadap tindakan yang dilakukan serta perkiraan biaya pengobatan

k. Memberikan persetujuan dan penolakan atas tindakan yang akan dilakukan oleh tenaga kesehatan terhadap penyekit yang dideritanya

1. Didampingi keluarga dalam keadaan kritis

m. Menjalankan ibadah sesuai dengan agama tau kepercayaan yang dianutnya selama hal itu tidak mengganggu pasien lain

n. Memperoleh keamanan dan keselamatan dirinya selama dalam perawatan di Rumah Sakit 
Tahun 2009 Tentang Rumah Sakit ada hak pasien untuk didampingi keluarga dalam keadaan kritis, dalam keadaan kritis dapat difahami sebagai suatu keadaan di mana pasien berada keadaan menjelang kematian, sehingga pasien perlu untuk didampingi keluarga untuk mendapatkan bimbingan rohani sesuai dengan agama dan kepercayaannya. Hak pasien untuk didampingi keluarga dalam keadaan kritis dan dalam pelayanan kesehatan tertentu memiliki dimensi yang berbeda karena jika pasien sudah dalam keadaan yang kritis maka Rumah Sakit wajib untuk meminta keluarganya mendampingi pasien tersebut, akan tetapi hak untuk didampingi keluarga terdekat dalam pelayanan kesehatan tertentu pasien tidak harus pasien berada dalam keadaan kritis, bisa saja pasien berada dalam keadaan sadar, setengah, sadar atau pun tidak sadar sama sekali terutama pada saat pasca-operasi, pada saat berada dalam ruang tertentu, terutama dalam ruangan yang dapat menimbulkan potensi terjadinya tindak kejahatan dan penyimpangan yang dilakukan oleh tenaga kesehatan baik yang berhubungan dengan diri pasien maupun terhadap harta benda pasien yang dipakai atau berada di dalm ruangan tersebut. Dalam teori terjadinya kejahatan timbulnya kejahatan terjadi karena adanya niat dan kesempatan, hanya adanya niat belum tentu seseorang akan melakukan kejahatan karena kesempatan untuk melakukan kejahatan tidak ada, akan tetapi adanya suatu keadaan tertentu yaitu adanya peluang untuk melakukan suatu kejahatan maka pada saat itu akan timbul niat untuk melakukan kejahatan, jadi dalam hal ini yang paling besar pengaruhnya adalah karena adanya kesempatan. Wilcox (1991) mengindentifikasikan tiga elemen yang harus ada sebagai syarat terjadinya suatu kejatahatan. Ketiga elemen tersebut adalah desire (niat), ability (kemampuan) dan opportunity

o. Mengajukan usul, saran, perbaikan atas perlakukan Rumah Sakit terhadap dirinya

p. Menolak pelayanan bimbingan rohani yang tidak sesuai dengan agama dan kepercayaan yang dianutnya

q. Menggugat dan/atau menuntut Rumah Sakit apabila Rumah Sakit diduga memberikan pelayanan yang tidak sesuai dengan standar baik secara perdata maupun pidanan; dan

r. Mengeluhkan pelayanan Rumah Sakit yang tidak sesuai dengan standar pelayanan melalui media cetak dan elektronik sesuai dengan ketentuan peraturan perundang-undangan. (kesempatan). ${ }^{11}$ Satu hal lagi yang perlu mendapat pengaturan adalah hak pasien untuk ditangani oleh tenaga kesehatan yang berjenis kelamin yang sama dengan pasien, hal ini merupakan perluasan hak pasien untuk memilih tenaga kesehatan yang diinginkannya.

Beberapa rumah sakit sebenarnya telah menetapkan hospital by law sebagai aturan khusus yang berlaku di rumah sakit masingmasing seperti yang diterapkan oleh Rumah Sakit Daerah dr. H. Soemarno Sosroatmodjo, dalam aturan hak dan kewajiban keluarga pasien salah satunya diatur bahwa "keluarga pasien memperoleh kesempatan untuk mengunjungi atau mendampingi pasien sesuai dengan peraturan yang berlaku". ${ }^{12}$ Walaupun tidak spesifik mengatur tentang kebolehan keluarga pasien untuk mendampingi pasien dapat dimaknai bahwa pada dasarnya keluarga pasien diberi hak untuk mendampingi pasien dalam keadaan dan tempat apapun, hal ini merupakan suatu upaya agar tidak terjadi perilaku yang dapat merugikan pasien. Demikian pula yang ditetapkan oleh RSU William Booth Semarang, dalam aturan rumah sakit tertuang ketentuan tentang Perlindungan Pasien dari Kekerasan Fisik, Perlindungan Terhadap Bayi, Orang cacat, Lemah, Beresiko dan Manula, salah satu ketentuannya adalah "staf dilarang memaksakan kehendak, mencaci, meneror, mengancam, atau membuly pasien dalam menjalankan asuhan atau menjalankan prosedur medis". ${ }^{13}$

Tidak adanya hak pasien untuk didampingi keluarga dalam kondisi dan di ruang tertentu akan memicu adanya kesempatan untuk terjadinya kejahatan yang dilakukan oleh tenaga kesehatan, karena sebagaimana yang telah peneliti sampaikan bahwa niat dapat timbul seketika jika adanya kesempatan untuk melakukan kejahatan diikuti adanya kemampuan untyuk melakukan kejahatan, hal ini menunjukkan telah terjadinya kekosongan norma (rechtvacuum) akibat dari kekosongan hukum akan mengakibatkan terjadi ketidakpastian hukum (rechtsonzekerheid) dan akibat dari ketidakpastian hukum akan

\footnotetext{
${ }^{11}$ Jurnal Srigunting, Teori Niat dan Kesempatan (+Kemampuan) Dalam Kejahatan Terorisme, diakses tanggal 29 Juni 2018.

${ }^{12}$ Sumber: UPT BLUD RSD dr. H. Soemarno Sosroatmodjo

${ }^{13}$ Sumber: RSU William Booth Semarang
} 
terjadinya kekacauan hukum (rechtverwaring) ${ }^{14}$. Oleh karena itu Pasal 32 Undang-Undang Nomor 44 Tahun 2009 Tentang Rumah Sakit harus segera diubah dengan memasukkan klausul hak pasien untuk didampingi keluarga pada saat kondisi dan di ruang tertentu, dalam praktiknya selama ini pasien hanya didampingi keluarga pada saat kritis, pada saat pemberian persetujuan tindakan medis, pada saat di ruang perawatan, tetapi dengan berbagai macam alasan pasien tidak boleh didampingi oleh keluarga terdekat seperti di ruang pemeriksaan seperti rontgent dan sebagainya.

Hukum yang berfungsi untuk memberikan perlindungan hukum kepada masyarakat terhadap potensi terjadinya kejahatan dalam pelayanan kesehatan harus mengaturnya secara tegas dalam peraturan perundang-undangan sehingga dapat menutup potensi terjadinya tindakan pelecehan seksual dan sejenisnya terhadap pasien, pintu terjadinya pelecehan seksual yang terjadi selama ini karena tidak adanya pendamping pasien dalam kondisi dan di ruang tertentu, dan undang-undang juga harus memberikan hak kepada pasien dan keluarganya atas permintaan untuk memilih tenaga kesehatan yang diinginkan oleh pasien terutama permintaan untuk ditangani oleh tenaga kesehatan yang berjenis kelamin yang sama dengan pasien.

\section{Urgensi hak pasien untuk didampingi keluarga dalam kondisi dan ruang tertentu}

Urgensi agar pasien didampingi keluarga dalam kondisi dan ruang tertentu dalam pelayanan kesehatan adalah:

a. Untuk memberikan perlindungan yang lebih besar kepada pasien yang sedang berada dalam keadaan tidak memiliki kemampuan untu bertindak dalam pelayanan kesehatan tertentu, terutama dalam kondisi kesadaran yang tidak stabil dan dalam ruangan tertentu yang hanya boleh dimasuki oleh orang-orang tertentu;

b. Untuk memberikan perlindungan kepada rumah sakit menutup potensi terjadinya kejahatan atau perilaku menyimpang dari tenaga kesehatan yang berkeja di rumah sakit;

c. Untuk memberikan kekuatan hukum kepada rumah sakit untuk menindak secara tegas

${ }^{14}$ Tiar Ramon, Kekosongan Hukum, diakses tanggal 29 Juni 2018. terhadap perilaku penyimpang yang dilakukan oleh tenaga kesehatannya;

d. Dapat dijadikan dasar bagi rumah sakit dalam melakukan perekrutan tenaga kesehatan yang akan berkerja yang memiliki kemampuan dan karakter yang baik dalam melayani pasien.

Dalam hukum pidana berlaku adigium "jika tidak diatur, berarti boleh dilakukan", yang berkembang menjadi konstruksi hukum "argumentum a contrario", jika tidak dilarang, berarti boleh. ${ }^{15}$ Bagi orang awan hukum menilai bahwa adigium ini merupakan sesuatu dalil yang dapat digunakan untuk melakukan sesuatu agar tidak terjerat dalam kasus hukum tertentu, akan tetapi bagi para aktivis hukum baik akademisi, praktisi hukum (polisi, jaksa, hakim, pengacara, notaris) harus memiliki pemahaman yang mendalam tentang adigium ini, bahwa apakah ketiadaan aturan norma seseorang tidak dapat dipersalahkan?,

\section{SIMPULAN}

Dari hasil penelitian yang telah dilakukan maka dapat ditarik beberapa kesimpulan yaitu:

1. Perlindungan hukum terhadap pasien untuk memperoleh pelayanan kesehatan merupakan hal yang sangat mendasar dan diatur dalam konvensi internasional dan dalam peraturan perundang-undangan di Indonesia

2. Undang-Undang Nomor 44 Tahun 2009 Tentang Rumah Sakit tidak mengatur secara khusus hak pasien untuk didampingi oleh keluarganya dalam kondisi dan ruang tertentu

3. Pasien dalam kondisi tertentu merupakan orang yang tidak memiliki keberdayaan untuk melakukan sesuatu bahkan tidak mampu untuk menolak tindakan yang dilakukan oleh orang lain terhadap dirinya, oleh sebab itu suatu keharusan seorang pasien untuk didampingi oleh keluarganya dalam setiap pelayanan kesehatan di Rumah Sakit

\section{DAFTAR PUSTAKA}

\section{Buku}

Alexandra Indriyanti Dewi. 2008. Etika dan

Hukum Kesehatan. Pustaka Book

Publisher. Yogyakarta.

Bahder Johan Nasution. 2005. Hukum Kesehatan pertanggungjawaban dokter. Rineka Cipta, Surabaya.

${ }^{15}$ Trainer dan Konsultan Hukum Shietra, Tidak diatur, artinya Boleh atau Dilarang?, diakses tanggal 29 Juni 2018. 
Departemen Kesehatan RI.1987. Sistem Kesehatan Nasional. Depkes RI, Jakarta.

Elfindri.2003. Ekonomi Layanan Kesehatan. Andalas University Press, Padang.

Endang Kusuma Astuti. 2006. Transaksi Terapeutik dalam Upaya Pelayanan Medis di Rumah Sakit. Citra Aditya Bhakti, Semarang.

J. Guwandi.2004. Hukum Medik (Medical Law). Fakultas Kedokteran Universitas Indonesia, Jakarta.

Muladi. 2009. Hak Asasi Manusia. Refika Aditama, Bandung.

\section{Jurnal/Majalah Ilmiah}

Veronica Komalawati,2004. Aspek Hukum Dalam Pelayanan Kesehatan: Suatu Kajian, Jurnal Hukum Bisnis Nomor 2 Tahun 2004. Jakarta.

Jurnal Srigunting, Teori Niat dan Kesempatan (+Kemampuan) Dalam Kejahatan Terorisme.

Makalah Seminar/ Disertasi

Bambang Giatno.2008. Makalah Seminar dalam Kongres XIV IBI, Padang.

Peraturan Perundang-undangan

Undang-Undang Dasar 1945

Undang-undang

Republik Indonesia, Undang-Undang Nomor 36 Tahun 2009 Tentang Kesehatan (Lembaran Negara Republik Indonesia Tahun 2009 Nomor 1441, Tambahan Lembaran Negara Republik Indonesia Nomor 5063)

Republik Indonesia, Undang-Undang Nomor 44 Tahun 2009 Tentang Rumah Sakit (Lembaran Negara Republik Indonesia Tahun 2009 Nomor 153, Tambahan Lembaran Negara Republik Indonesia Nomor 5072)

Republik Indonesia, Undang-Undang Nomor 36 Tahun 2014 Tentang Tenaga Kesehatan (Lembaran Negara Republik Indonesia Tahun 2014 Nomor 298, Tambahan Lembaran Negara Republik Indonesia Nomor 5607)

\section{Konvensi Internasional}

United Nation Organization (UNO), The Universal Declaration of Human Right (UDHR), 1948.

Konvensi Internasional Tentang Hak Ekonomi, Sosial dan Budaya (ECOSOC). 2200 A (XXI) Tanggal 16 Desember 1966.

Peraturan lain-lain

Peraturan Rumah Sakit RSD dr. H. Soemarno Sosroatmodjo Kabupaten Bulungan
Peraturan Rumah Sakit William Booth Semarang 